\title{
A NEW PORCELLANID CRAB FROM MIDDLE JAPAN
}

AUTHOR(S):

Miyake, Sadayoshi

CITATION:

Miyake, Sadayoshi. A NEW PORCELLANID CRAB FROM MIDDLE JAPAN. PUBLICATIONS OF THE SETO MARINE BIOLOGICAL LABORATORY 1957, 6(1): 75-78

ISSUE DATE:

1957-06-30

URL:

http://hdl.handle.net/2433/174572

RIGHT: 


\title{
A NEW PORCELLANID CRAB FROM MIDDLE JAPAN ${ }^{12}$ )
}

\author{
SADAYOSHI MIYAKE \\ Zoological Laboratory, Faculty of Agriculture, Kyushu University, Fukuoka
}

With 3 Text-figures

A new species of Porcellana described below was taken in the Tanabe Bay, Wakayama-ken, living commensally with spicular corals, Dendronephthya gloriosa and $D$. castanea.

I wish to express my hearty thanks to Dr. Huzio UtinomI for his courtesy in handing the material over to me. I am also grateful to Prof. Dr. Yoshi Kuni Hrraiwa of the Kyushu University for his constant guidance.

\section{Porcellana maculata sp. nov.}

Diagnosis.-Carapace and legs smooth, glabrous; carapace slightly convex, not at all areolated; front as a rule four-lobed, of which median two lobes very broad. There is an acuminate tooth behind the post-ocular angle; lateral margin of carapace with an acute tooth. First peduncle of antennule with a few granulated ridges; inner angles of both anterior crests projecting upwards. Merus of third maxilliped with a round crest. Chelipeds unequal. Wrist with a laminate crest along the inner margin, the crest is entire in larger individuals, but serrated in smaller ones; fingers of the larger cheliped with an obtuse tooth on both inner margins, but those of the smaller one with minute teeth. Ambulatory legs of a moderate length; propodus with three or four spinules; dactylus with three spinules. Telson seven-lobed, the central one being very small. This species is commonly found on spicular corals, Dendronephthya. Carapace and cheliped marked with red spots.

Description of holotype-Male, $\left.\mathrm{cl}^{3)} 3.8 \mathrm{~mm}, \mathrm{cb}^{4}{ }^{4}\right) 3.3 \mathrm{~mm}$. Carapace slightly longer than broad, a little convex, smooth, not all areolated. Front four-lobed, much produced forwards. There is an acuminate tooth behind the post-ocular angle. Lateral margin of carapace armed with an acute tooth.

1) Contributions from the Zoological Laboratory, Faculty of Agriculture, Kyushu University, No. 231.

2) Contributions from the Seto Marine Biological Laboratory, No. 294.

$3,4)$ The abbreviation cl. is used for "length of carapace", cb. for "breadth of carapace".

Publ. Seto Mar. Biol. Lab., VI (1), 1957. (Article 5) 
First peduncle of antennule a little longer than broad, ventral surface smooth, upper surface furnished with a few granulated ridges running transversely, inner angles of both anterior crests projecting upwards. Peduncles of antenna smooth, cylindrical; second peduncle armed with an acuminate spinule on upper margin. The relative lengths of basal peduncles are II $:$ III $: I V=1: 1.3: 1$. Third maxilliped smooth; ventral surface of ischium ornamented with oblique ridges, the crest of merus much produced inwards.

Cheliped unequal, the right one being larger; surface smooth, glabrous like the carapace. Arm longer than broad, upper anterior margin undulated; its upper distal end of the right side acuminate, but that of the left obtuse; the lower margin prolonged at its distal end into rather acute spine. Wrist longer than broad, and

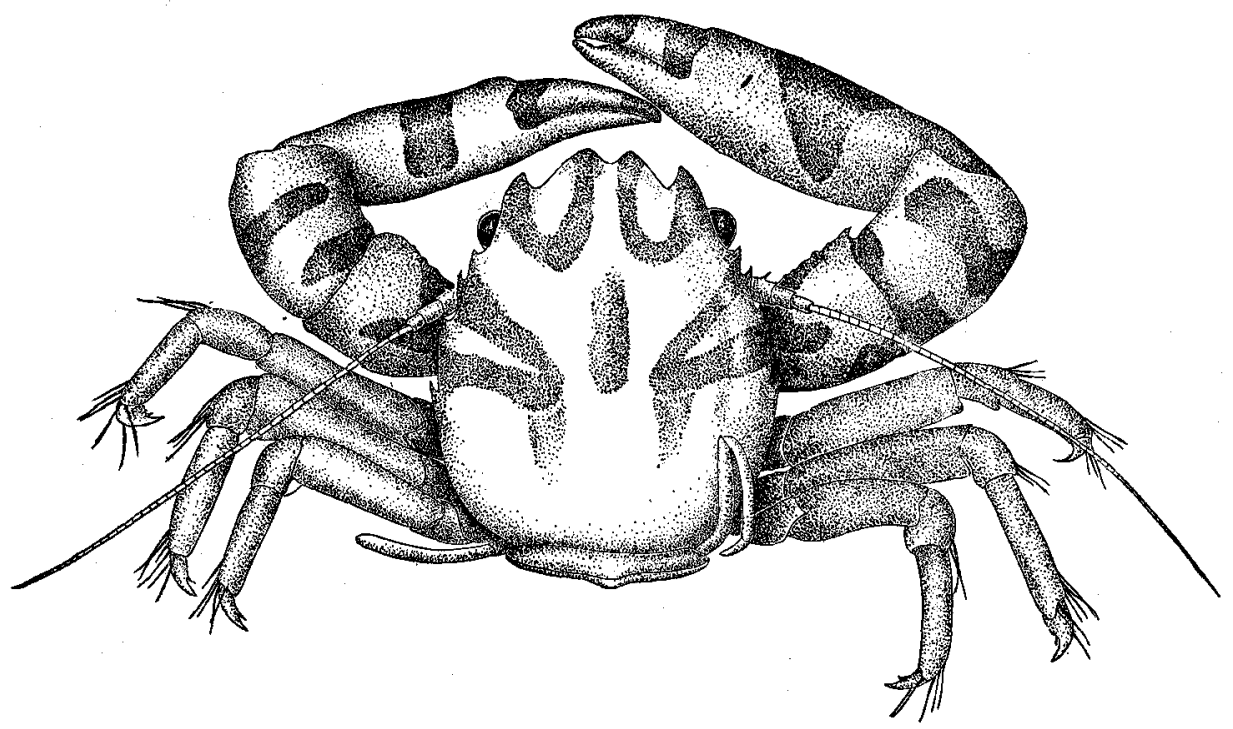

Fig. 1. Porcellana maculata sp. nov,, male, holotype, $\times 8$.

provided with a laminate, entire crest on inner margin. The length of palm a little longer than twice the breadth, its lower surface slightly produced. Fingers of right side very short, and one-third the palm; immovable finger armed with an obtuse tooth at the middle of inner margin; movable finger also with an obtuse tooth at the base. Fingers of left (smaller) side rather slender, a little longer than half the length of palm, and furnished with minute teeth along the inner margin; there is no gap between fingers.

Ambulatory legs smooth, glabrous, of a moderate length. Merus unarmed, 3.5 times as broad as long. Carpus furnished with a few hairs on outer distal margin. Propodus 3.8 times as broad as long, and armed with four spinules, of which the two at distal end being in pair, another one just in front of them, and the remaining one 
at the middle of the segment; the last mentioned spinule is absent from the first and third pairs.

Telson seven-lobed, the central lobe being very small.

Paratypes.-Two males, cl. 2.6, cb. 2 ; cl. 2.5, cb. $1.7 \mathrm{~mm}$. These specimens are very similar to the holotype, differing in only a few characters.

Front four-lobed, of which median two lobes subdivided irregularly into many minute teeth on inner margins; wrist armed with three acuminate teeth on inner margin.

Colour in alcohol.--Light brown, marked with reddish colour-patterns as in the text-figure 1 .

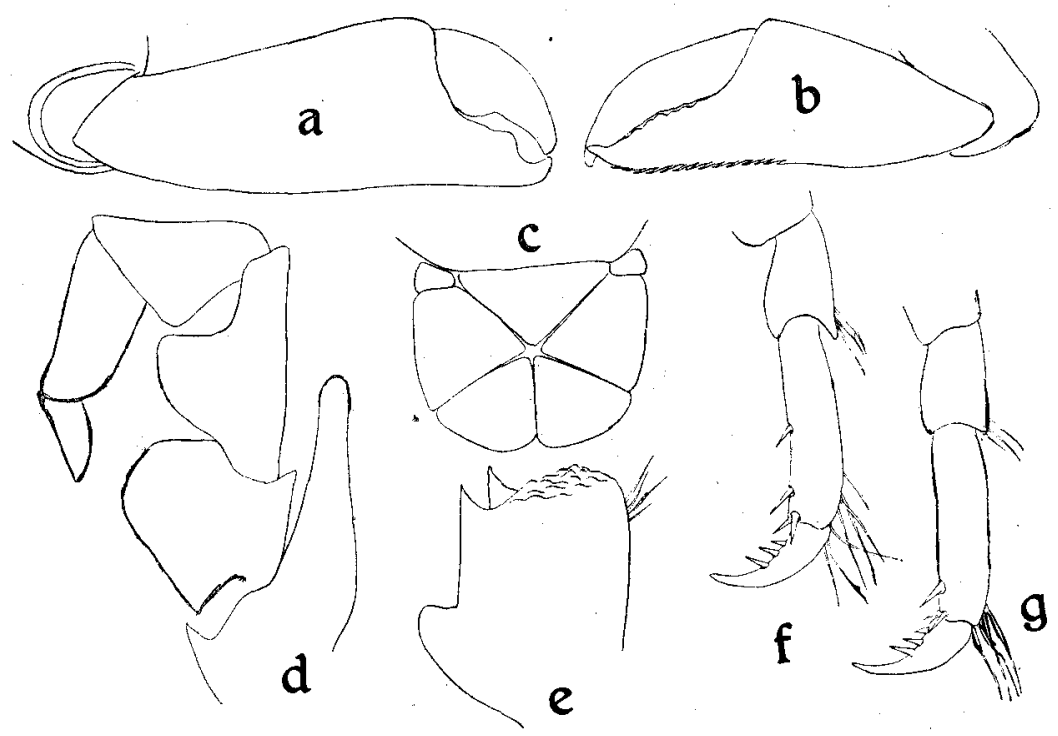

Fig. 2. Porcellana maculata sp. nov., holotype.

$a$, Outer view of right chela, $\times 12, b$. outer view of left chela, $\times 12 . \quad c$. telson, $\times 12$. $d$, lower view of left third maxilliped, $\times 25$. $e$, lower view of first peduncle of left antennule, $\times 40$. $f$, second ambulatory leg, $\times 8 . g$, third ambulatory leg, $\times 8$.

Relationships.--This species is closely allied to Porcellana armata DANA, but may be distinguished from it at first sight by the characters of the median lobes of carapace and chelipeds.

Disposition of types.-Holotype (S. M. B. L. Type 164), male is deposited in the Seto Marine Biological Laboratory, Shirahama, Wakayama-ken. Paratypes, two males, are deposited in the Zoological Laboratory, Faculty of Agriculture, Kyushu University, Fukuoka.

Type locality and habitat.-The specimens of holotype and paratypes were taken from the shore of Shisô-jima, Tanabe Bay, Wakayama-ken, on May 1, 1954, living 
commensally with Dendronephthya gloriosa Utinomi, collected by a gill-net of spinylobster fishing.

Remarks.-According to Mr. Torao Yамамото, this species is found at the shore of Susami, Wakayama-ken, in April, 1954, attached to D. gloriosa. And also found in Tanabe Bay, attached to $D$. castanea UTinom.

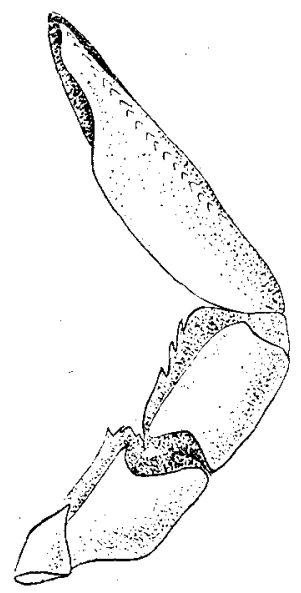

b

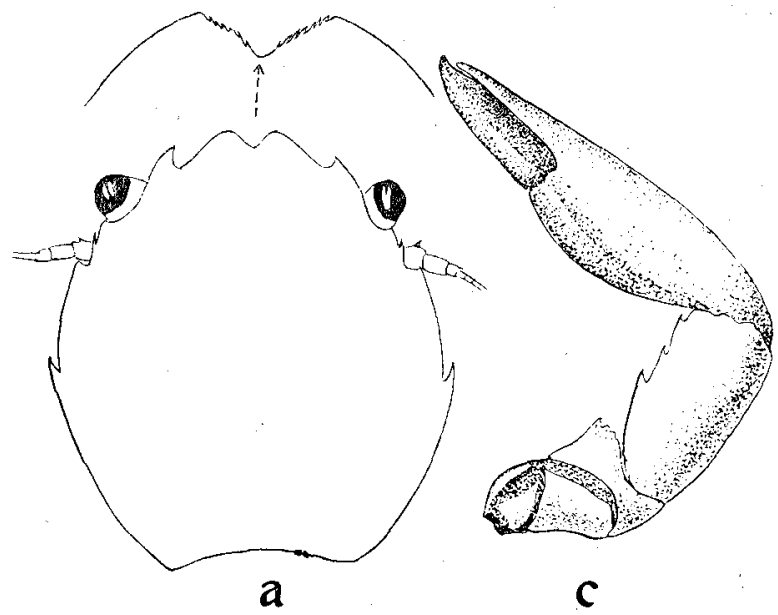

a

Fig. 3. Porcellana maculata sp. nov., male, paratype.

$a$, Dorsal view of carapace, $\times 10 . b$, ventral view of left cheliped, $\times 10 . c$, dorsal view of right cheliped, $\times 10$.

\section{LITERATURE CITED}

DaNA, T. D. 1852. Crustacea.-United States Exploring Expedition during the years 1838-1842, ....., Philadelphia, 13: 1-1620; 1855, pls. 1-96.

Miyake, S. 1942. Studies on the Decapod Crustaceans of Micronesia. III. Porcellanidae. Palao Trop. Biol. Stat. Stud., Tokyo, 2 (3): 329-379, pl. 1, text-figs. 1-35.

1943. Studies on the crab-shaped Anomura of Nippon and adjacent waters. J. Dep.

Agric. Kyushu Imp. Univ., Fukuoka, 7 (3): 49-158, text-figs. 1-62. 